\title{
Genetic Correlation Between Female Fertility and Milk Yield in Lacaune Sheep
}

\author{
I. David, ${ }^{* 1}$ J. M. Astruc, † G. Lagriffoul,† E. Manfredi, ${ }^{*}$ C. Robert-Granié, ${ }^{*}$ and L. Bodin* \\ *INRA UR 631, Station d'Amélioration Génétique des Animaux, 31320 Castanet-Tolosan, France \\ †Institut de l'élevage-ANIO, 31320 Castanet-Tolosan, France
}

\section{ABSTRACT}

A total of 416,670 lactations for 189,101 ewes from 3,603 sires and distributed across 1,978 herd-year groups were used to estimate genetic and environmental parameters of standardized milk yield $\left(\mathrm{SMY}_{\mathrm{T}}\right)$, fertility in ewe lambs $\left(\mathrm{PR}_{1}\right)$, and fertility in adult ewes $\left(\mathrm{PR}_{\mathrm{A}}\right)$. Parameters were estimated with a multiple-trait sire linear model. Heritabilities for $\mathrm{SMY}_{\mathrm{T}}, \mathrm{PR}_{1}$, and $\mathrm{PR}_{\mathrm{A}}$ were 0.27 (0.009), 0.04 (0.004), and 0.05 (0.004), respectively. These results were in accordance with the literature. The genetic correlation between $\mathrm{PR}_{1}$ and $\mathrm{PR}_{\mathrm{A}}$ was 0.55 , indicating that fertility is not the same trait in ewe lambs and adult ewes. The genetic correlation between milk yield and lamb fertility was not significantly different from zero. The genetic correlation between milk yield and fertility in adult ewe $(-0.23)$ was in the range of antagonistic correlations reported in dairy cattle. Consequently, these results show that selection for milk yield can induce an indirect decrease in fertility. Nevertheless, no phenotypic decrease in fertility in artificial insemination matings has been observed in this population. This is the first time that correlation between milk yield and fertility is reported in sheep and further investigations are needed to confirm this result.

Key words: fertility, milk yield, sheep, genetic correlation

\section{INTRODUCTION}

In dairy cattle, the genetic correlations between female fertility and milk production are antagonistic (Boichard et al., 2002; Wall et al., 2003; GonzalezRecio et al., 2006). This relationship partly explains the decline in fertility observed in many dairy breeds

Received February 21, 2008.

Accepted May 19, 2008.

${ }^{1}$ Corresponding author: Ingrid.David@toulouse.inra.fr that have been intensively selected for milk production (VanRaden et al., 2004; Andersen-Ranberg et al., 2005). To limit this decrease, many countries have included female fertility in the breeding scheme of dairy cattle (Interbull, 2007).

In French dairy sheep, the primary selection objective has been milk production, and for the last decade increasing attention has been given to functional traits like disease resistance (e.g., mastitis, scrapie) and udder morphology but not to reproduction traits (Barillet et al., 2006; Marie-Etancelin et al., 2006; Barillet, 2007). Genetic parameters for dairy traits are similar for sheep and cattle (Barillet, 1997). Milk yield has a moderate heritability (approximately 0.30) and is highly correlated with fat and protein yields (Barillet and Boichard, 1987). In the same way, genetic parameters for fertility traits are comparable and very low $\left(\mathrm{h}^{2}\right.$ $<0.06$ ) in both (Clarke and Hohenboken, 1983; David et al., 2008). In contrast to cattle, no phenotypic decrease of fertility has been observed in sheep, even in the Lacaune breed, which has been intensively selected for dairy traits for more than $30 \mathrm{yr}$. In this species, in a one-lambing-per-year system, mating generally occurs about 5 mo after the lactation peak, just before or after drying off. Therefore, some researchers suggest that there cannot be an antagonism between female fertility and milk production in sheep (Barillet, 2007); but the genetic correlation between these 2 traits has never been estimated in this species.

The objective of this study was to estimate the genetic correlation between milk yield and female fertility after AI in the French Lacaune sheep. This latter trait is a binary phenotype that indicates that the female lambed (1) or did not lamb (0) after AI.

\section{MATERIALS AND METHODS}

\section{Reproduction Management}

The study considered dairy Lacaune ewes from the nucleus of the selection scheme. They were bred in the southwest of France where they are managed in an annual lambing system. Each year more than $80 \%$ of 
Table 1. Characteristics of the data set used for genetic parameter estimation

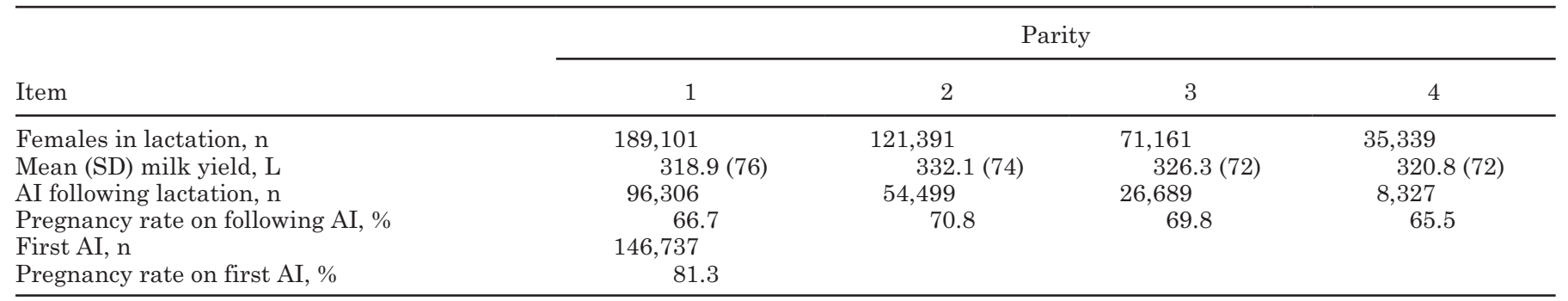

the ewes of the nucleus herds are artificially inseminated over a short period between June and August. The ewes receive a single synchronization treatment (fluorogestone acetate vaginal sponge inserted for $14 \mathrm{~d}$; pregnant mares' serum gonadotropin injection at withdrawal) and are inseminated without regard to estrus expression. Inseminated females are systematically joined with males 6 to $7 \mathrm{~d}$ after insemination to ensure conception by natural mating. The other females are mostly naturally mated without synchronization. Because there is no pregnancy test, the interval between insemination and lambing is used to determine the successful insemination (artificial or natural). During the first month of lactation, although lambs are suckled, ewes are milked (once a day). After lamb weaning (1 mo of age), ewes are milked twice a day for 6 to 8 mo. At the next breeding season (June-July), ewes can be artificially inseminated again. With this management, an AI occurs, on average, 1 yr after the previous AI, and consequently at the end of the lactation period. Milk recording follows the International Committee on Animal Recording (ICAR) recommendations (ICAR, 2007) and consists of a maximum of 7 monthly records. In this nucleus, the replacement rate of adult ewes is about $30 \%$.

\section{Data}

Data came from the French national performances recording scheme, which holds pedigree and ewe performance information (SIEOL: Système d'Information
En Ovin Lait from CTIG: Centre de Traitement de l'Information Génétique, Jouy-en-Josas, France). Each standardized milk yield produced during the 2002 to 2006 period was associated with the result of the following AI. First-lactation records were also associated with their previous AI result (first AI of the ewe). To avoid potential culling biases in genetic analysis (Kadarmideen et al., 2003), a record from the jth parity (for $j>1$ ) was accepted only if the $(j-1)$ th parity was also observed. For instance, the milk yield record of a second parity was not included if the milk yield of the first parity was not recorded. The same requirement of previous lactation applies to all later parities. Similarly, the second AI record of a ewe was only accepted if the first AI record was observed, and so on. For the same parity, if lactation was observed but not $\mathrm{AI}$, the AI result was set as missing. Female careers were limited to the first 4 lactations. Milk yield was estimated from monthly records according to the ICAR recommendations (ICAR, 2007) and was standardized according to the milking period length and the lactation number (Barillet et al., 1992). Mean standardized milk yield for lactations was $324 \pm 75 \mathrm{~L}$. The AI result was defined as a binary trait and was considered as a success when lambing occurred 142 to $152 \mathrm{~d}$ after AI (gestation period); otherwise, it was a failure. First AI performed in young ewes $(<1 \mathrm{yr})$ was considered as a different trait than AI performed in adult ewes. The percentage success was $81.3 \%$ for the first AI and $68.3 \%$ for adult AI records.

The final data set consisted of 416,670 lactation records, 146,737 first AI records, and 185,821 adult

Table 2. Heritability (SE; on the diagonal), and genetic (SE; above the diagonal) and phenotypic (below the diagonal) correlations for milk yield $\left(\mathrm{SMY}_{\mathrm{T}}\right)$, young $\left(\mathrm{PR}_{1}\right)$ and adult $\left(\mathrm{PR}_{\mathrm{A}}\right)$ fertility

\begin{tabular}{llcc}
\hline & \multicolumn{1}{c}{$\mathrm{PR}_{1}$} & \multicolumn{1}{c}{$\mathrm{PR}_{\mathrm{A}}$} & $\mathrm{SMY}_{\mathrm{T}}$ \\
\hline $\mathrm{PR}_{1}$ & $0.04(0.004)$ & $0.55(0.05)$ & $-0.06(0.05)$ \\
$\mathrm{PR}_{\mathrm{A}}$ & 0.03 & $0.05(0.004)$ & $-0.23(0.04)$ \\
$\mathrm{SMY}_{\mathrm{T}}$ & 0.03 & -0.05 & $0.27(0.009)$ \\
\hline
\end{tabular}


AI records (AI records except first AI) of 189,101 ewes issued from 3,603 sires and distributed across 1,978 herd-year groups. The characteristics of this data are given in Table 1.

\section{Methods}

A multiple-trait linear sire model was used to perform the analysis. The 3 traits considered in the model were the standardized milk yield considering that it is the same trait for all parity (SMYT), and 2 different traits for female fertility: fertility in female lambs (pregnancy rate after first AI: PR1), and fertility in adult ewes (PRA). The equation for SMYT was the one used for the French national genetic evaluation (Astruc et al., 2002). Therefore, the fixed effects included were year-age within lactation number combination (38 levels), the year-month within lactation number combination (76 levels), the combination between year and the interval from lambing to first test-day in 10-d intervals except for first ( 0 to $24 \mathrm{~d}$ ) and last (55 to $77 \mathrm{~d}$ ) levels within lactation number (56 levels), and the year-herd combination (1,978 levels). Following results obtained in a previous study (David et al., 2007), fixed effects included in the equation for PR1 were the year-month of AI combination (27 levels) and age of the female at $\mathrm{AI}$ in midmonth (3 levels). The fixed effects included in the equation for PRA were the year-month of AI combination (24 levels), interval lambing-AI in months (6 levels), and the female age in years (4 levels). In addition, the equations for PRi ( $\mathrm{i}=1$ or $\mathrm{A}$ ) included 2 random environmental effects: the service male (868 and 2,345 levels for PR1 and PRA, respectively) and the year-insemination group within herd combination (2,579 and 3,282 levels for PR1 and PRA, respectively). Other random effects included were the genetic additive effect of the sire $\left(u_{P R_{1}}, u_{P R_{A}}, u_{S M Y_{T}}\right.$ for PR1, PRA, and SMYT, respectively) with

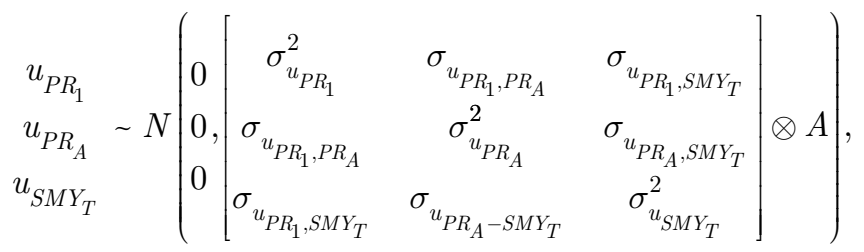

where $A$ is the relationship matrix, and the random permanent environmental effect of the female in the equation for $\mathrm{PR}_{\mathrm{A}}$ and $\mathrm{SMY}_{\mathrm{T}}\left(p_{P R_{A}}, p_{S M Y_{T}}\right.$ for $\mathrm{PR}_{\mathrm{T}}$ and $\mathrm{SMY}_{\mathrm{T}}$, respectively) is

$$
\begin{gathered}
p_{P R_{A}} \\
p_{S M Y_{T}}
\end{gathered} \quad N\left(\begin{array}{l}
0 \\
0
\end{array}\left[\begin{array}{cc}
\sigma_{p_{P R A}}^{2} & \sigma_{p_{P R A}, p_{S M Y T}} \\
\sigma_{p_{P R A}, p_{S M Y T}} & \sigma_{p_{S M Y T}^{2}}^{2}
\end{array}\right]\right) .
$$

The pedigree file included 17,794 animals. The models were fitted using ASReml software (Gilmour et al., 2002).

\section{RESULTS AND DISCUSSION}

Even if the outcome of an insemination is a binary variable, we used analysis methods for continuous data, which is not theoretically appropriate (Wright, 1934; Gianola, 1982). Nevertheless, as demonstrated by several authors, we have shown in a previous study (David et al., 2007) that the continuous approximation can be used for studying adult AI results of French sheep. Because of the high probability of AI success in young ewes, the linear approximation is less obvious for $\mathrm{PR}_{1}$ (Meijering and Gianola, 1985). Nevertheless, we performed a separate analysis of $\mathrm{PR}_{1}$ using 2 singletrait sire models: linear and threshold models. The correlation between breeding values estimated with these 2 models was $>0.99$, indicating that the linear approximation will not have consequences in the correlations between traits estimated in this study. We used a sire model on data selected according to the previous event. Similar analysis (results not shown) performed on subsets of the data with different data structure (data selected or not in accordance with the previous lactation or AI records) and models (sire or animal model) gave the same results as the one presented in this article.

Estimated heritabilities and phenotypic and genetic correlations are presented in Table 2. The heritability estimated for standardized milk yield was moderate (0.27) and in accordance with previous studies for sheep or cattle (Barillet and Boichard, 1987; Kadarmideen et al., 2003; Gonzalez-Recio et al., 2006). Milk yield repeatability was moderate $(0.55)$ and conformed to the small ruminant literature (Analla et al., 1996; El-

Table 3. Correlation between residual (SE; above the diagonal) and between permanent environmental effect (below the diagonal) for milk yield $\left(\mathrm{SMY}_{\mathrm{T}}\right)$, young $\left(\mathrm{PR}_{1}\right)$ and adult $\left(\mathrm{PR}_{\mathrm{A}}\right)$ fertility

\begin{tabular}{lccr}
\hline & $\mathrm{PR}_{1}$ & $\mathrm{PR}_{\mathrm{A}}$ & \multicolumn{1}{c}{$\mathrm{SMY}_{\mathrm{T}}$} \\
\hline $\mathrm{PR}_{1}$ & & $0.02(0.004)$ & $0.04(0.004)$ \\
$\mathrm{PR}_{\mathrm{A}}$ & $-{ }^{1}$ & $-0.15(0.009)$ & $-0.01(0.003)$ \\
$\mathrm{SMY}_{\mathrm{T}}$ & $-{ }^{1}$ & - \\
\hline
\end{tabular}

${ }^{1}$ No permanent environmental effect for $\mathrm{PR}_{1}$. 
Saied et al., 1999). Heritabilities estimated for young and adult female fertility were low (0.04 and 0.05, respectively) and in accordance with previous studies (Weigel and Rekaya, 2000; Varona and Noguera, 2001; David et al., 2008). Repeatability of adult fertility after AI was also low (0.14), which indicates the low predictive power of a single AI result on lifetime reproductive performance.

Phenotypic correlation between milk yield and its following AI result is very close to zero $(-0.05)$. Nevertheless, this result is in accordance with other studies in which milk production is negatively related to subsequent reproductive performances (Gootwine and Pollott, 2000; Pollott and Gootwine, 2004; David et al., 2008).

The correlations between residual values were low between all traits (Table 3). This means that all genetic and environmental factors having a strong and common effect on both groups of traits have been included in the model.

The correlation between permanent environmental effects for $\mathrm{SMY}_{\mathrm{T}}$ and $\mathrm{PR}_{\mathrm{A}}$ was low and negative $(-0.15)$ but significantly different from zero (Table 3). As stated by Kadarmideen et al. (2000), there is a lack of published information on estimates of permanent environmental correlation between fertility and milk production traits. However, in their study, those authors also found an antagonistic correlation between permanent environmental effect for fertility to first service and milk yield.

The genetic correlation estimated between $\mathrm{PR}_{1}$ and $\mathrm{PR}_{\mathrm{A}}$ was positive (0.55) and significantly different from 1 , indicating that female fertility of young and adult ewes does not correspond to the same trait. The negative genetic correlation estimated between $\mathrm{SMY}_{\mathrm{T}}$ and $\mathrm{PR}_{\mathrm{A}}\left(\mathrm{r}_{\mathrm{g}}=-0.23\right)$ was significantly different from zero. Because this is the first time that this correlation has been estimated in sheep, there are no comparable results in the literature for this species. However, this correlation falls into the range for cattle breeds reported by Boichard et al. (2002) for the relationship between the same variables: $r_{g}=-0.11$ to -0.32 . However, it is slightly less negative than the result reported in cattle by Kadarmideen et al. (2000): $r_{g}=-0.42$. The genetic correlation between first AI and milk yield $(-0.06)$ was not significantly different from zero.

The probability of AI success has decreased in French dairy cattle during the last decade (Barbat et al., 2005) as well as in cattle from other countries (Lucy, 2001). This decrease is partly explained by the antagonistic genetic correlation between fertility and milk yield (VanRaden, et al., 2004; Andersen-Ranberg et al., 2005). In contrast to dairy cattle, the probability of AI success in French dairy sheep has increased during the last 20 yr (Figure 1), particularly in the Lacaune breed for which the trend is about 0.03 fertility points per year. In the Lacaune breed, selection for milk yield induces an important direct genetic progress: about $6 \mathrm{~L}$ per year $\left(0.2 \sigma_{g}\right.$; Barillet, 2007). According to the negative genetic correlation, the indirect response on adult AI fertility due to milk selection should be about -0.005 fertility points per year in this breed. The discrepancy between the observed genetic decrease and the actual phenotypic trend may be explained by 3 main reasons. The first reason is a regular improvement of environmental conditions that may compensate for the genetic trend. In fact, for several years French AI centers have been paying more attention to all factors that may affect insemination results. For instance, a technician of the AI center performs the synchronization treatment or makes sure that the breeder is aware of these acts and will execute them at the right time. Also, AI centers pay more attention when measuring concentration, volume, and motility of semen. However, because some centers are in competition they do not reveal their practices that permit even small improvements of AI success. The second reason is a possible selection on fertility. In the breeding management of the Lacaune population, not all ewes of a herd are inseminated in each breeding period; a proportion (about $20 \%$ ) is naturally mated. Under the advice of the AI centers, breeders pay more attention in choosing which ewes to inseminate at each breeding season (Vacaresse and Briois, 1998). They choose the ewes to inseminate among the most productive ones and according to the previous reproduction results. This trend has been observed for several years and has become a rule; a ewe that does not get pregnant after 1 or 2 consecutive AI is not inseminated further. These practices may realize a real genetic selection because replacement ewes are mainly issued from $\mathrm{AI}$ and consequently from the most fertile dams. There were not enough years of recording in this study to evaluate the genetic trend in fertility and to confirm this hypothesis. The third reason is that breeding management (selection of the female for AI, for instance) induces bias in the estimation. If true, it indicates that routine field records cannot be used for studying the genetic correlation between fertility and milk yield in French sheep. Therefore, results have to be confirmed on other data sets.

The correlation between production and reproduction has only been investigated for the female side (female fertility-milk yield). Nevertheless, the outcome of an insemination depends both on male and female fertility (Varona and Noguera, 2001; Piles et al., 2005; David et al., 2007). Estimating genetic correlation between male fertility and milk production would be an interesting further analysis. Nevertheless, because heritability 


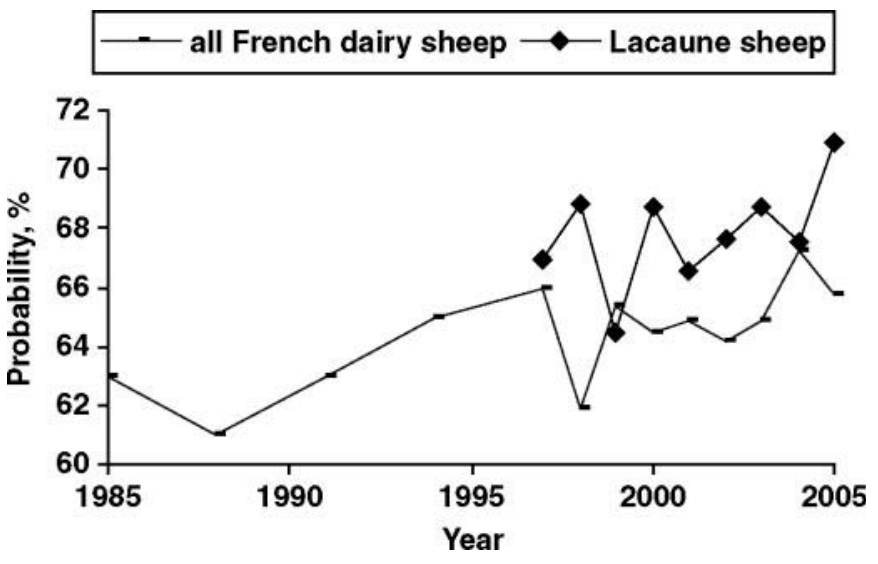

Figure 1. Evolution of the probability of AI success in French dairy sheep from 1985 to 2005 (Perret and Lagriffoul, 2005).

of the male fertility is very low $(<0.5 \%$; David et al., 2008 ), the genetic correlation estimate would likely not be precise.

\section{CONCLUSIONS}

The results obtained in this study suggest that there is an antagonistic genetic correlation between female fertility after AI and milk yield in sheep. Despite this result, and in contrast to dairy cattle, selection for milk yield in French sheep has not previously been associated with a decrease in fertility. Changes in reproduction management have probably compensated for the genetic decline in fertility in this species. This study was a first attempt to estimate the genetic correlation between female fertility and milk yield in sheep; these results need to be validated.

\section{ACKNOWLEDGMENTS}

The authors thank the ministère de l'Agriculture for supporting this study in the frame of a "BELIA action," directed by ANIO and INRA, and the AI centers that provided the data. We thank Wendy Brand-Williams for editing of the English language.

\section{REFERENCES}

Analla, M., I. Jimenez-Gamero, A. Munoz-Serrano, J. M. Serradilla, and A. Falagan. 1996. Estimation of genetic parameters for milk yield and fat and protein contents of milk from murcianogranadina goats. J. Dairy Sci. 79:1895-1898.

Andersen-Ranberg, I. M., G. Klemetsdal, B. Heringstad, and T. Steine. 2005. Heritabilities, genetic correlations, and genetic change for female fertility and protein yield in Norwegian dairy cattle. J. Dairy Sci. 88:348-355.

Astruc, J. M., F. Barillet, A. Barbat, V. Clement, and D. Boichard. 2002. Genetic evaluation of dairy sheep in France. Pages 231-
234 in 7th World Congress on Genetics Applied to Livestock Production, Montpellier, France.

Barbat, A., T. Druet, B. Bonaiti, F. Guillaume, J. J. Colleau, and D. Boichard. 2005. Overview of phenotypic fertility results after artificial insemination in the three main French dairy cattle breeds. Pages 137-140 in Rencontres Recherches Ruminants, Paris, France.

Barillet, F. 1997. Genetics of milk production. Pages 539-564 in The genetics of sheep. L. Piper and A. Ruvinsky, ed. CAB International, Oxford, UK.

Barillet, F. 2007. Genetic improvement for dairy production in sheep and goats. Small Rumin. Res. 70:60-75.

Barillet, F., J. M. Astruc, and G. Lagriffoul. 2006. Functional traits in small dairy ruminants: Genetic variation and relationship with milk production. In Proc. 8th World Congr. Genet. Appl. Livest. Prod., Belo Horizonte, MG, Brazil. Instituto Prociencias, Minas Gerais, Belo Horizinte, Brazil.

Barillet, F., and D. Boichard. 1987. Studies on dairy production of milking ewes. I. Estimates of genetic parameters for total milk composition and yield. Genet. Sel. Evol. 19:459-474.

Barillet, F., D. Boichard, A. Barbat, J. M. Astruc, and B. Bonaiti. 1992. Use of an animal model for genetic evaluation of the Lacaune dairy sheep. Livest. Prod. Sci. 31:287-299.

Boichard, D., A. Barbat, and M. Briend. 2002. Evaluation génétique des caractères de fertilité femelle chez les bovins laitiers. Pages 5-9 in Association pour l'étude de la reproduction animale, journée reproduction, génétique et performances, Paris, France.

Clarke, S. E., and W. D. Hohenboken. 1983. Estimation of repeatability, heritability and breed differences for lamb production. J. Anim. Sci. 56:309-315.

David, I., L. Bodin, G. Lagriffoul, C. Leymarie, E. Manfredi, and C. Robert-Granié. 2007. Genetic analysis of male and female fertility after AI in sheep: Comparison of single trait and joint models. J. Dairy Sci. 90:3917-3923.

David, I., C. Robert-Granié, E. Manfredi, G. Lagriffoul, and L. Bodin. 2008. Environmental and genetic variation factors of artificial insemination success in French dairy sheep. Animal 2:979986.

El-Saied, U. M., J. A. Carriedo, L. F. de la Fuente, and F. San Primitivo. 1999. Genetic parameters of lactation cell counts and milk and protein yields in dairy ewes. J. Dairy Sci. 82:639-644.

Gianola, D. 1982. Theory and analysis of threshold characters. J. Anim. Sci. 54:1079-1096.

Gilmour, A. R., B. J. Gogel, B. R. Cullis, S. J. Welham, and R. Thompson. 2002. ASReml User Guide Release 1.0. VSN International Ltd., Hemel Hempstead, UK.

Gonzalez-Recio, O., R. Alenda, Y. M. Chang, K. Weigel, and D. Gianola. 2006. Selection for female fertility using censored fertility traits and investigation of the relationship with milk production. J. Dairy Sci. 89:4438-4444.

Gootwine, E., and G. E. Pollott. 2000. Factors affecting milk production in improved Awassi dairy ewes. Anim. Sci. 71:607-615.

ICAR. 2007. Recording Guidelines. ICAR, Rome Italy.

Interbull (International Bull Evaluation Service). 2007. Interbull Routine genetic evaluation for dairy production traits, February 2007. Available http://www-interbull.slu.se/eval/framesida-prod. htm

Kadarmideen, H. N., R. Thompson, M. P. Coffey, and M. A. Kossaibati. 2003. Genetic parameters and evaluations from single- and multiple-trait analysis of dairy cow fertility and milk production. Livest. Prod. Sci. 81:183-195.

Kadarmideen, H. N., R. Thompson, and G. Simm. 2000. Linear and threshold model genetic parameters for disease, fertility and milk production in dairy cattle. Anim. Sci. 71:411-419.

Lucy, M. C. 2001. Reproductive loss in high-producing dairy cattle: Where will it end? J. Dairy Sci. 84:1277-1293.

Marie-Etancelin, C., E. Manfredi, M. R. Aurel, F. Pailler, J. Arhainx, E. Ricard, G. Lagriffoul, P. Guillouet, B. Bibe, and F. Barillet. 2006. Genetic analysis of milking ability in Lacaune dairy ewes. Genet. Sel. Evol. 38:183-200. 
Meijering, A., and D. Gianola. 1985. Linear versus nonlinear methods of sire evaluation for categorical traits: A simulation study. Genet. Sel. Evol. 17:115-131.

Perret, G., and G. Lagriffoul. 2005. Compte rendu annuel sur l'insémination artificielle ovine. Institut de l'élevage-ANIO, Castanet-Tolosan, France.

Piles, M., O. Rafel, J. Ramon, and L. Varona. 2005. Genetic parameters of fertility in two lines of rabbits with different reproductive potential. J. Anim. Sci. 83:340-343.

Pollott, G. E., and E. Gootwine. 2004. Reproductive performance and milk production of Assaf sheep in an intensive management system. J. Dairy Sci. 87:3690-3703.

Vacaresse, C., and M. Briois. 1998. To improve AI fertility results by choosing females according to past reproduction records. Page 91 in Rencontres recherches ruminants, Paris, France.
VanRaden, P. M., A. H. Sanders, M. E. Tooker, R. H. Miller, H. D. Norman, M. T. Kuhn, and G. R. Wiggans. 2004. Development of a national genetic evaluation for cow fertility. J. Dairy Sci. $87: 2285-2292$

Varona, L., and J. L. Noguera. 2001. Variance components of fertility in Spanish Landrace pigs. Livest. Prod. Sci. 67:217-221.

Wall, E., S. Brotherstone, J. A. Woolliams, G. Banos, and M. P. Coffey. 2003. Genetic evaluation of fertility using direct and correlated traits. J. Dairy Sci. 86:4093-4102.

Weigel, K. A., and R. Rekaya. 2000. Genetic parameters for reproductive traits of Holstein cattle in California and Minnesota. J. Dairy Sci. 83:1072-1080.

Wright, S. 1934. An analysis of variability in number of digits in an inbred strain of guinea pigs. Genetics 19:506-536. 